\title{
Comparison of Foliar Spray and Side Dressing of Potassium on Growth, Flowering, Productions of Corms in Gladiolus cv. Yellow Stone
}

\author{
Shehzadi Saima ${ }^{1}$, Maqsoda Perveen², Muhammad Nawaz ${ }^{1}$, Khalid M. Ahmad,", and Haider Sultan ${ }^{1}$ \\ ${ }^{1}$ Institute of Pure and Applied Biology, Bahauddin Zakariya University, Multan, Pakistan; ${ }^{2}$ Department of statistics, Bahauddin \\ Zakariya University, Multan, Pakistan.
}

Abstract | Potassium is a macro nutrients that play a key role in development and growth of plants.
Therefore, the present study was planned to test the effects of potassium on Gladiolus by different
treatment methods, and to find out which method is more promising. The corms of Gladiolus hybrid
cv. yellow stone was used for plantation. Experiment was carried out in complete randomized design
(CRD) with four replications and three fertilizer treatments (control, $2 \mathrm{~g} /$ pot with side dressing, $2 \mathrm{~g} /$
pot with foliar spray). Results revealed that foliar spray of potassium enhanced most of parameters
i.e. length of stalk, fresh weight of stalk, dry weight of stalk, number of florets per plant, diameter
of stalk, fresh and dry weight of leaves, number of leaves significantly at P<0.01 more than side
dressing. Although side dressing of potassium also increased the plant growth to some extent more
than control, however, number of cormels per plant was decreased. Therefore, it can be concluded that
application of potassium by foliar spray is more effective in increasing the growth and flowering of
Gladiolus than side dressing.
Received $\mid$ April 12, 2020; Accepted | March 29,2021; Published | May 23,2021
*Correspondence | Khalid M. Ahmad, Institute of Pure and Applied Biology, Bahauddin Zakariya University, Multan, Pakistan; Email:
kmahmad786@gmail.com, khalidmasod@bzu.edu.pk
Citation | Saima, S., M. Perveen, M. Nawaz, K.M. Ahmad and H. Sultan. 2021. Comparison of foliar spray and side dressing of potassium on
growth, flowering, productions of corms in gladiolus cv. yellow stone. Sarbad Journal of Agriculture, 37(2): 548-554.
DOI | https://dx.doi.org/10.17582/journal.sja/2021/37.2.548.554
Keywords | Cut flowers, Gladiolus, Growth and yield, Cormels, Macronutrient, Potassium.

\section{Introduction}

G ladiolus (Gladiolus grandiflorus) is a cormous, perennial and flowering plants belongs to family Iridaceae. It grows from rounded and symmetrical corms. Their stems are generally un-branched, producing longitudinally grooved and narrow leaves that are covered by a sheath. The inflorescences bear either one or many flowers. The spikes of flowers are large, one-sided and bisexual. The petals and sepals are almost similar in appearance are called as tepals. A tube like structure is formed at the base by union of these tepals. The flowers have different colors ranging from red to orange or creamy to white or purple to reddish/pink with white markings. Due to consumption of flowers in religious, industrial and social activities, growers put high values to diverse floral plants and thus floriculture has arose as a cash business (Riaz et al., 2007). In order to earn more economic return and to flourish the business growers started growing non-conventional plants i.e. cut flowers. Recently this credit of investments with high return has improved awareness in the people to live in sound and healthy environment. The desire of decoration of flowers in restaurants and hotels has flourished this business also (Ahmad et al., 2008). In Pakistan, in top selling cut flowers, Gladiolus (Gladiolus grandiflorus L.) comes after rose (Riaz et June 2021 | Volume 37 | Issue 2 | Page 548 
al., 2007). Among cut flowers gladioli are considered elite as it has superb vase life with various shapes and hues (Bose et al., 2003). It lies at the top due to its beauty, glamour keeping quality, various colors, shades and shapes, hence it is called as "Queen of Bulb". The ecological and weather conditions of Punjab, Pakistan are favorable for the good production of gladiolus. In the local market although many varieties are available, but special characteristics required by the global markets are still lacking. For the improvement in the quality and yield of flowers there is always need to develop new varieties with promising characters.

Quality of flowers, production of corms as well as growth are directly affected by fertilizers. Appropriate amount of fertilizers with balanced quantities produce maximum number of flowers in gladiolus. Macronutrients contribute a lot in the growth and yield of plants as they play a vital role in physiology of them. The deficiencies of these nutrients affected adversely the yield of crops in different areas. The main causes of nutrient deficiency are reduced availability and use of farmyard manure, loss of top soil by erosion, intensive cropping and liming of soil (Fragaria et al., 2002). Among the most chief macronutrients, potassium is very vital as it affects the growth and physiology of gladiolus. Most of soils are deficient in potassium after phosphorus and nitrogen (Salisbury and Ross, 1992). In light sandy soils potassium can be easily leached down as it is more mobile than phosphorus but less than nitrates. According to Hartmann et al. (1981) the soils having very low potassium can fix it in the soils to make it available to plants but this is not fixed permanently as the reactions is reversible. In fertilization of gladiolus potassium is the key nutrient. Several authors suggested that potassium is required in higher rates than phosphorus and nitrogen (Wilfret, 1980; Zubair et al., 2006; Zorb et al., 2014). In higher plants potassium is major macronutrient as it is crucial for photosynthesis, protein synthesis and enzyme activation (Michail et al, 2004). In gladiolus it significantly affected the opening of first floret and days for emergence of spike (Butt, 2005). Deficiency of potassium cause yellowing of younger and older leaves and interveinal chlorosis. Its deficiency also decreased count of buds, delayed flowering as well as reduced flower stem (Wilfret, 1980). Reduced potassium availability also produced weak roots and stems that are easily attacked by disease causal agents. Due to these factors plants can be easily lodged (bent to ground) either by rain or by wind (Salisbury and
Ross, 1992). Due to importance of potassium in the physiology of plants, this study was designed to check the effect of $\mathrm{K}$ on gladiolus growth either by sidedressing and foliar spray.

\section{Materials and Methods}

An experiment was performed in the garden of Department of Horticulture, Bahauddin Zakariya University, Multan. Gladiolus hybrid cv. Yellow stone was used. Pots ( $30 \mathrm{~cm}$ in diameter) were filled with $3 \mathrm{~kg}$ of soil, consisted of clay (60\%), farmyard manure (10\%) and leaf-manure (30\%). Experiment was performed in complete randomized design (CRD) with four replications and three fertilizer treatments. The corms of gladiolus with size of $7-8 \mathrm{~cm}$ in circumference were planted in pots on October 2019.

The treatments used in this experiment are: (I) $T_{1}$, control; (ii) $\mathrm{T}_{2}$, side dressing (2g/pot); and (iii) $\mathrm{T}_{3}$, foliar spray $(2 \mathrm{~g} /$ pot $)$.

Application was started one month after planting the corms and then $2^{\text {nd }}$ and $3^{\text {rd }}$ applications at three week interval throughout the growing season. The recommended doses of nitrogen and phosphorous were applied for soil amendment of all the three treatments. Other agricultural practices i.e. watering and weeding were carried out for all plants whenever it was required.

\section{Data recorded}

Following parameters were recorded during the experiment:

\section{Length of stalk $(\mathrm{cm})$}

Length of stalk was measured from bottom to top with scale in all samples collected from each experimental unit and their average was calculated.

\section{Number of leaves per plant}

Number of leaves was counted in all samples and their average was calculated and this process was repeated for all remaining treatments.

\section{Fresh weight of stalk $(g)$}

Fresh weight of stalk was measured by using weight balance and their average was calculated.

\section{Dry weight of stalk (g)}

Dry weight of stalk was measured by using weight 
balance and their average was calculated.

\section{Diameter of stalk ( $\mathrm{mm}$ )}

The diameter of stalk was measured by using Vernier calipers. The diameter of stalk was measured from its mid and their average was calculated.

\section{Number of flowers per stalk}

Number of flowers per stalk was counted and their average was calculated.

\section{Number of corms per plant}

It was seen visually that there was any out growth formed on corm planted and their average was calculated.

\section{Fresh weight of leaves $(g)$}

Leaves were separated from stalk and then weight was measured by using weight balance and their average was calculated.

\section{Dry weight of leaves (g)}

Leaves were dried in oven for $48 \mathrm{~h}$ and then weight was measured by using weight balance and their average was calculated.

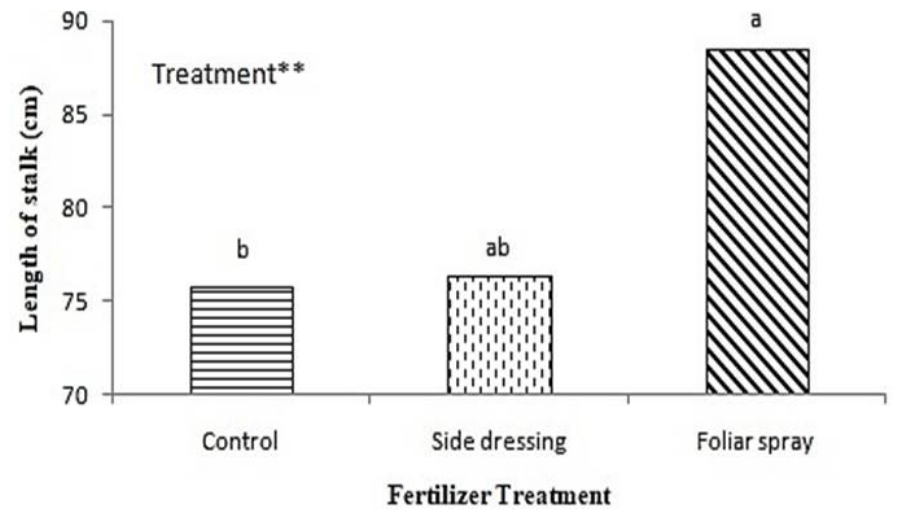

Figure 1: Length of flower stalk in gladiolus after different methods of $K$ applications.

\section{Results and Discussion}

Length of stalk (cm)

Length of stalk was significantly affected by $\mathrm{K}$ treatments in overall analysis of variance. Application of $2 \mathrm{~g}$ K foliar with recommended doses of nitrogen and phosphorous gave the tallest length of stalk. However, insignificant differences were recorded between plants treated as side-dressing and controls (Fig. 1). In cut flowers the foliar application of potassium may have caused better accumulation of assimilates that produced sturdier, stronger and taller stalks (Arvinter et al., 2015).

\section{Number of leaves per plant}

Number ofleaves per plant was significantly influenced by treatments of $\mathrm{K}$ combined with recommended doses of $\mathrm{N}$ and $\mathrm{P}$ at $\mathrm{P}<0.01$. Figure 2 showed that as compared to control, side-dressing of $\mathrm{K}$ improved the number of leaves. Foliar spray was more effective and significantly enhanced the leaves number as compared to untreated plants. The foliar application with higher doses of $\mathrm{K}$ and with NP enhanced the vegetative growth of the plants by increasing the number of leaves (Sarwar et al., 2013). More leaves production is related to increase meristematic activity, caused by potassium (Verma and Verma, 2007). The balance quantity of nutrients improves the growth of plant as well as vigor due to protein accumulation; therefore, more leaves are produced by the plants (Shah et al., 2014).

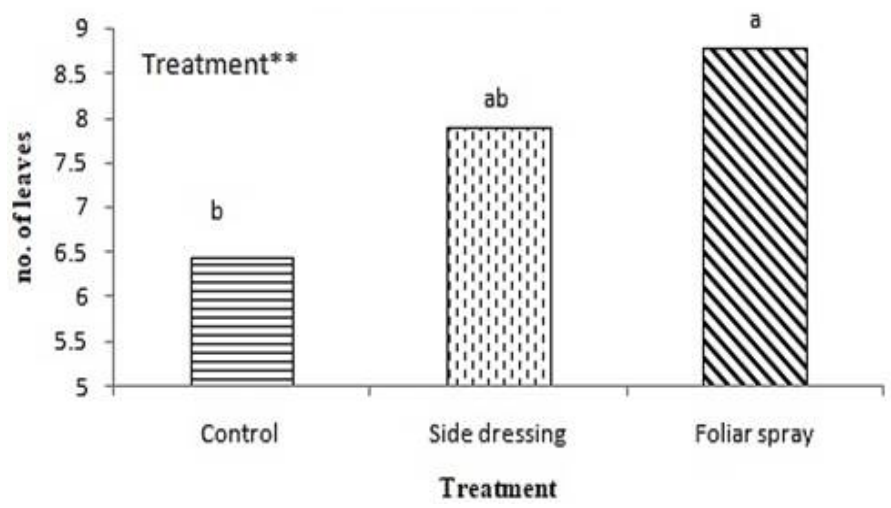

Figure 2: Number of leaves in gladiolus after different methods of $K$ applications.

\section{Fresh and dry weight of leaves- plant $^{-1}(g)$}

Fresh weight of leaves of Gladiolus was significantly affected by $\mathrm{K}$ applications (Table 1). Data illustrated in Figure 3 clearly showed that the Treatment-3 fertilizing the plants with foliar spray combined with recommended doses of $\mathrm{N}$ and $\mathrm{P}$ resulted in the highest fresh weight of leaves.

In dry weight ofleaves, plants fertilized with foliar spray of $\mathrm{K}$ showed highest significant values as compared to soil dressing. Therefore, ANOVA detected significant differences between different treatments of K. Side dressing treatment showed stimulatory effect on dry weight of leaves as compared to untreated controls (Fig. 3). This stimulation in leaves fresh and dry weights by application of potassium was also reported in peanut by Ali and Mowafy (2003), Baubinia variegata by Mazher et al. (2007) and mung bean by 
Table 1: Analysis of variance (ANOVA) for length of stalk, number of leaves, fresh weight of stalk, dry weight of stalk, diameter of stalk, number of flowers per stalk, number of corms, fresh weight of leaves and dry weight of leavesin Gladiolus cv. yellow stone under potassium treatments.

\begin{tabular}{|llllllllll}
\hline Source & $\begin{array}{l}\text { Length } \\
\text { of stalk }\end{array}$ & $\begin{array}{l}\text { No. of } \\
\text { leaves }\end{array}$ & $\begin{array}{l}\text { Fresh } \\
\text { weight of } \\
\text { stalk }\end{array}$ & $\begin{array}{l}\text { Dry } \\
\text { weight of } \\
\text { stalk }\end{array}$ & $\begin{array}{l}\text { Diameter } \\
\text { of stalk }\end{array}$ & $\begin{array}{l}\text { No. of } \\
\text { flowers } \\
\text { per stalk }\end{array}$ & $\begin{array}{l}\text { No. of } \\
\text { corms }\end{array}$ & $\begin{array}{l}\text { Fresh } \\
\text { weight of } \\
\text { leaves }\end{array}$ & $\begin{array}{l}\text { Dry weight } \\
\text { of leaves }\end{array}$ \\
\hline Treatment & $6.13^{*}$ & $8.64^{* *}$ & $6.62^{* * *}$ & $7.05^{* *}$ & $15.50^{* * *}$ & $10.69^{* *}$ & $6.50^{* *}$ & $25.91^{* * * *}$ & $23.38^{* * * *}$
\end{tabular}

$*=$ Significant $(P<0.05) ; *$ * highly significant $(P<0.01) ; F$ values are given.

Thalooth et al.(2006). They described that K promoted the growth parameters i.e. dry weight of leaves and number of leaves. The stimulation in leaf parameters in gladiolus upon application of $\mathrm{K}$ could be due to enhancement in various characters i.e. more number of leaves per plant, $\mathrm{N}$ metabolism and photosynthetic activity provided more photosynthates to leaves. Thalooth et al. (2006) stated that foliar application of potassium resulted in higher weight, larger and greater number of leaves. These stimulatory effects could be due to the effect of $\mathrm{K}$ on enzyme activity, biological activities, on photosynthetic pigments and metabolism that subsequently promote plant's vegetative growth (Michail et al., 2004).

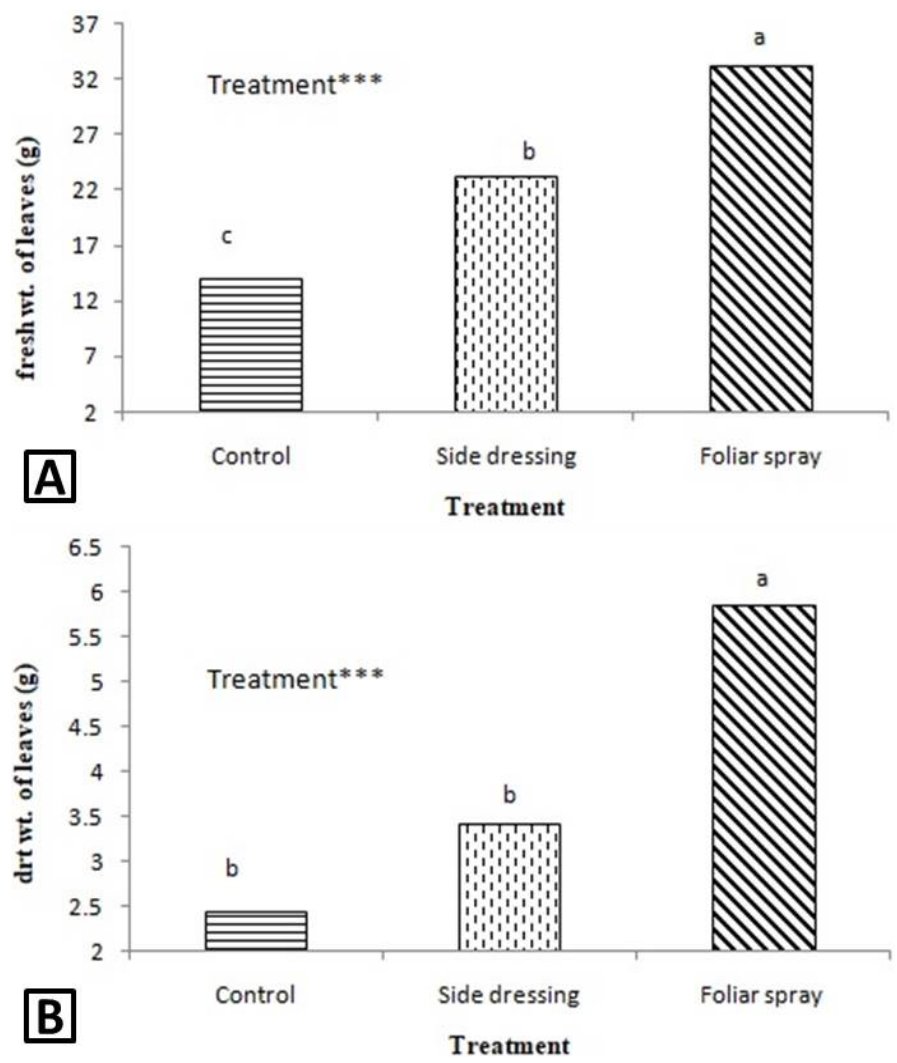

Figure 3: Fresh (A) and dry (B) weight of leaves in gladiolus after different methods of $K$ applications.

Fresh weight of stalk (g)

Potassium had a significant effect on fresh weight of stalk (Table 1). The maximum fresh stalk weight was observed in plants receiving $2 \mathrm{~g} /$ pot by foliar spray ${ }^{-1}$, followed by plants obtained $2 \mathrm{~g}$ /pot of potassium by side dressing (Fig. 4). Minimum fresh stalk weight was observed in control plants. The increase in fresh weight of stalk by potassium is due to the fact that potassium helps in protein synthesis that subsequently causes division of cells in flowers and stalk. Reproductive parts are also influenced by uptake of phosphorus which is enhanced by potassium. The outcome of our results are supported by effect of potassium, when adequate potassium was added in the nutrient medium of chrysanthemum, it produced maximum weight of reproductive parts. Similar results were described by Naggar (2009) that foliar spray containing $20 \%$ potassium enhanced the fresh weight of reproductive parts i.e. flower and stalk. The rate of 300 and $400 \mathrm{ppm}$ of potassium significantly increased the fresh weight of stalk. In marigold, application of potassium improved the fresh weight of stalk.

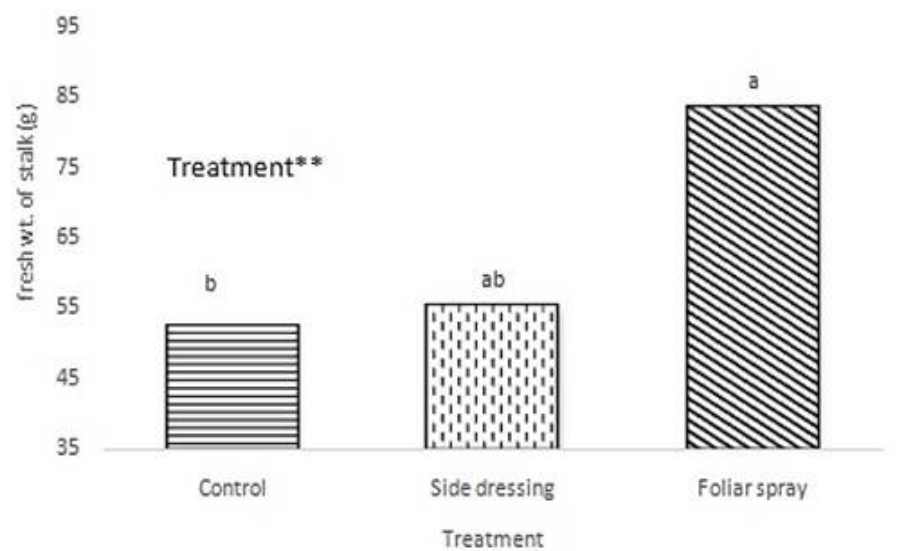

Figure 4: Fresh weight of stalk in gladiolus after different methods of $K$ applications.

Dry weight of stalk ( $g$ )

ANOVA had detected significant differences in dry weight of stalk under potassium treatments (Table 1). The foliar spray of potassium had increased dry weight of stalk to highest level than the plants treated by potassium in side dressing method and untreated plants. Side dressing application of potassium also 
increased the dry weight of stalk as compared to controls (Fig. 5). The increase in dry weight of stalk by foliar application of potassium may be due to affirmative role of $\mathrm{K}$ in development of more stalks that in turn increased the dry weight of stalk (Zubair, 2011). The $K$ increased the photosynthetic activity largely which in turn supplied more photosynthates and accumulation of these assimilates resulted in more growth of stalk in cut flowers (Arvinter et al., 2015).

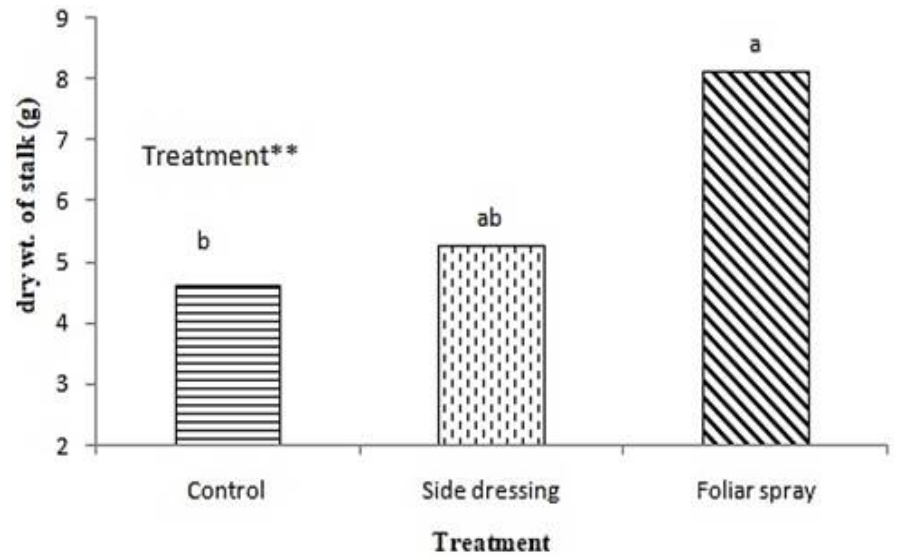

Figure 5: Dry weight of stalk in gladiolus after different methods of $K$ applications.

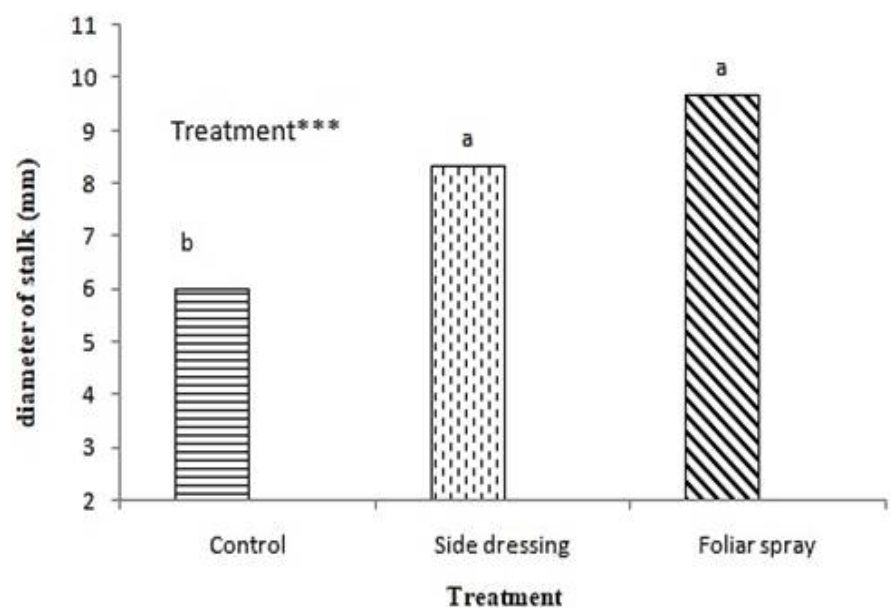

Figure 6: Diameter of stalk in gladiolus after different methods of $K$ applications.

\section{Diameter of stalk ( $\mathrm{mm}$ )}

Diameter of stalk in Gladiolus was significantly affected by $\mathrm{K}$ treatments at $\mathrm{P}<0.00$ (Table 1 ). Side dressing promoted diameter of stalk compared to control and reached to maximum level by foliar spray of K (Fig. 6). These results are parallel to conclusions of Mukesh et al. (2001) who described that foliar spray of $\mathrm{K}$ increased the floret diameter in Gladiolus. It was also observed that $\mathrm{K}$ along with $\mathrm{N}$ and $\mathrm{P}$ had stimulatory effects on floral characters in Dahlia (Younis et al., 2006). K with $\mathrm{P}$ also promoted floral diameter to maximum level in Gladiolus (Mohsin et al., 2015). This enhancement in floret diameter by foliar spray of $\mathrm{K}$ may be due to constructive role of $\mathrm{K}$ in development of floret (Zubair, 2011). Application of $\mathrm{K}$ had noteworthy effect on diameter of floret because macronutrients have vigorous role in development and growth of plant. Their catalytic and stimulatory effects had influence on different metabolic and physiological processes that significantly enhanced diameter of florets (Jat et al., 2007). This enhancement was chiefly due to the increase in number of leaves that could increase the manufacture of photosynthates required to increase reproductive growth (Sidhu and Arora, 1989).

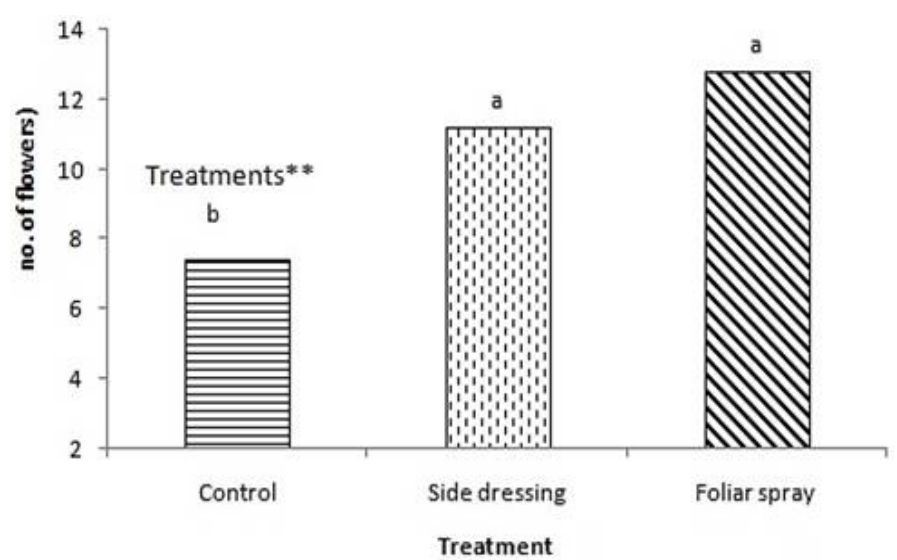

Figure 7: Number of flowers per stalk in gladiolus after different methods of $K$ applications.

Number of florets-spike ${ }^{-1}$

Highly significant $(\mathrm{P}<0.01)$ variations were observed by analysis of variance in treatments. Highest numbers of florets were observed upon foliar application of $\mathrm{K}$, although side dressing also enhanced number of florets as compared to control, but it came after foliar spray (Fig. 7). These results are in accordance with the results of Bhattacharjee (2001), Sharma et al. (2003), Naggar and Rahalia (2005) and Lehri et al. (2011). They stated that the maximum number of florets per spike and large flowers were obtained with application of $\mathrm{P}$ and $\mathrm{K}$ and rising levels of each element tended to improve the flower spike quality and corm growth. In xylem stream of plants, transport of nutrients and water were influenced by potassium that enhanced their transport (Bajwa and Rehman, 2005). Higher levels of potassium compensate the detrimental effects of high nitrogen. Low levels of potassium reduced the production of flowers (Joiner and Gruis, 1961). Similarly in marigold number of flowers was increased by potassium fertilization ( $\mathrm{Pal}$ and Ghosh 2010). Butt (2005) and Younis et al. (2006) observed that $\mathrm{K}$ and $\mathrm{P}$ had synergetic effect on number of flowers in dahlias. 
Number of cormels-plant ${ }^{-1}$

The statically highest number of cormels per plant was found in controls with no application of $\mathrm{K}$ and with recommended doses of $\mathrm{N}$ and $\mathrm{P}$ and minimum cormels were observed in fertilizing the plants with $\mathrm{K}$ foliar spray and $\mathrm{K}$ as soil dressing (Fig. 8). It was also observed that no prominent differences in number of cormels per plants were observed when potassium was applied either as soil dressing or foliar spray. These results are in contradiction with Barman et al. (1998) who stated that $\mathrm{K}$ had much more pronounced effects on size and weight of cormels. However present results are supported by findings of Arora and Khanna (2003) and Lehri et al. (2011).

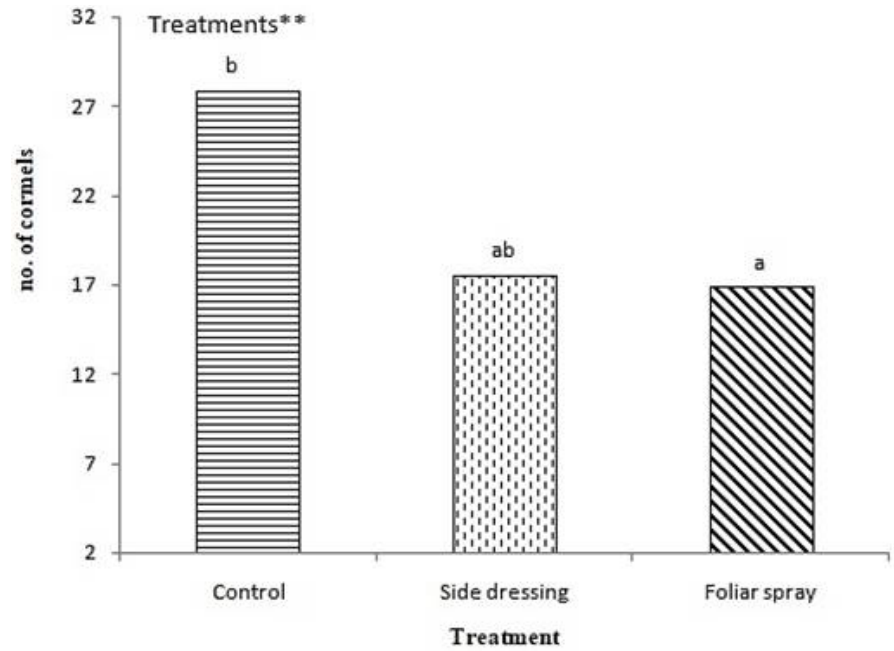

Figure 8: Number of cormels per plant in gladiolus after different methods of $K$ applications.

\section{Conclusions and Recommendations}

In general, it can be concluded that the application of potassium can remarkably influence the growth and yield related indices of Gladiolus vigorously in various ways. This study concluded that the number of leaves per plant, fresh and dry weight of leaves, number of florets per plant, fresh and dry weight of stalk, length and diameter of stalk were significantly affected by foliar application of potassium at the rate of $2 \mathrm{~g}$ per pot than side dressing and control treatments, therefore, the foliar application of potassium was best method to get maximum flowering production in gladiolus.

\section{Novelty Statement}

Potassium application is very crucial for the yield of cut flowers. If it is not applied by proper method then it can be wasted. Therefore in this study we compared two methods of potassium application and found that foliar spray is much more appropriate method to get better yield of gladiolus.

\section{Author's Contribution}

Khalid M. Ahmad conceived the idea and guided the study. Shehzadi Saima and Haider Sultan performed the experimental work. Shehzadi Saima, Muhammad Nawaz and Maqsoda Perveen wrote the manuscript. Maqsoda Perveen analyzed the statistical data.

\section{Conflict of interest}

The authors declare no conflict of interest.

\section{References}

Ahmad, T., I. Ahmad and M. Qasim. 2008. Present status and future prospects of gladiolus cultivation in Punjab, Pakistan. J. Tekirdag Agric., 5: 227-238.

Ali, A.A.G. and S.A.E. Mowafy. 2003. Effect of different levels of potassium and phosphorus fertilizer with the foliar application of zinc and boron on peanut in sandy soil. Zagazig J. Agric. Res., 30: 335-358.

Arora,J.B. and K. Khanna. 2003. Effect of nitrogen and pinching on growth and flower production of marigold (Tageteserecta). Indian J. Hort., 43: 291-294.

Arvinter, S., B. Sharma, B. Dilta, L. Nomita, Y. Gupta and S. Bhardwaj. 2015. Effects of fertilization on quality flower production and foliar nutrient content of carnation (Dianthus caryophyllus L.) cv. Master. Bangladesh J. Bot., 44: 133-137. https://doi.org/10.3329/bjb. v44i1.22736

Bajwa, M.I. and F. Rehman. 2005. Soil and Fertilizer Potassium. In: Soil science. National Book Foundation, Islamabad, Pakistan, pp. 318-320.

Barman, G.,S. Chanda and N. Roychoudhary. 1998. Production of corms and cormels of gladiolus through application of N, P and K. Horticul. J., 11: 87-92.

Bhattacharjee, S.K. 2001. Influence of N, P and K fertilization on flowering and corm production in gladiolus. Soil Fert. Abst., 45: 1041.

Bose, T.K., L.P. Yadav, P. Pal, V.A. Parthasarathy and P. Das. 2003. Commercial flowers, Vol. 2. NayaUdyog, Kolkata, India.

Butt, S.J. 2005. Effect of N, P, K on some flower quality and corm yield characteristics of gladiolus. Tekirdag J. Agric., 2: 212-214.

Fragaria, N. K., V.C. Baligar and R.B. Clark. 2002. Micronutrients in crop production. Adv. 
Agron., 77: 185-268. https://doi.org/10.1016/ S0065-2113(02)77015-6

Hartmann, H.T., W.J. Flocker and A.M. Kofranek. 1981. Soil and water management and mineral nutrition. In: Plant science- Growth, development and utilization of cultivated plants. Pearson Prentice Hall, New Jersey, USA, pp. 195-221.

Jat, R.N., S.K. Khandelwal and K.N. Gupta. 2007. Effect of foliar application of urea and zinc sulphate on growth and flowering parameters in African marigold (Tageteserecta Linn.), J. Ornam. Horticul., 10: 271-273.

Joiner, J.N. and J.T. Gruis. 1961. Effect of nitrogen and potassium levels on growth, flowering and chemical composition of Zinnia and Marigold. Horticulture Society, Florida, pp. 445-448.

Lehri, S.M., A.A. Kurd, M.A. Rind and N.A. Bangulza. 2011. The response of Gladiolus tristisL. to $\mathrm{N}$ and $\mathrm{P}_{2} \mathrm{O}_{5}$ fertilizers. Sarhad J. Agric., 27: 185-188.

Mazher, A.A.M., A.A. Yassen and S. M. Zaghloul. 2007. Influence of foliar application of potassium on growth and chemical composition of Baubinia variegata seedlings under different irrigation intervals. World J. Agric. Sci., 3: 2331.

Michail, T., T. Walter, W. Astrid, G. Walter, G. Dieter, S.J. Maria and M. Domingo. 2004. A survey of foliar mineral nutrient concentrations of Pinuscanariensis at field plots in Tenerife. Forest Ecol. Manage., 189: 49-55. https://doi. org/10.1016/j.foreco.2003.07.034

Mohsin , B., K. Imran, W. Rashid, Q. Khan, T. Mohsin, Z. Muhammad and A. Iftikhar. 2015. Growth and corm production of Gladiolus grandiflorus, L.'Essential' under different NPK regimes. J. Ornam. Plants, 6(1): 11-19.

Mukesh, K., T.K. Chattappadhyay, D.K. Das and M. Kumar. 2001. effect of foliar application of zinc, copper and iron on the yield and quality of Gladiolus cv. Mirela. J.f Interacad., 5: 300-303.

Naggar, A.H.E. 2009. Response ofDianthus caryophyllusL. plants to foliar nutrition. World. J. Agric. Sci., 5: 622-630.

Pal, P. andP. Ghosh.2010. Effect of different sources and levels of potassium on growth, flowering and yield of African marigold (Tegetes erecta Linn.) cv. 'siracule'. Indian J. Nat. Prod. Resour., 1: 371-375.

Riaz, T., S.N. Khan and A. Javaid. 2007. Scenario of gladiolus production in Punjab, Pakistan. Pak. J.
Bot., 39: 2389-2393.

Salisbury, F.B. and C.W. Ross. 1992. Mineral nutrition. In: Plant physiology, $4^{\text {th }}$ ed. Wadsworth Pub. Co. Belmont, California, pp. 116-135.

Sarwar, M., S. Rehman, C.M. Ayyub, W. Ahmad, J. Shafi and K. Shafique. 2013. Modeling growth of cut-flower stock (Matthiola incana R. Br.) in response to differing in nutrient level. Universal J. Food Nutr. Sci., 1: 4-10.

Shah, S.N.M., A. Ali, N. Amin, M. Shah and A. Khan. 2014. Potassium influence on flowering and morphology of Zinnia elegans. Int. J. Farming Allied Sci., 3: 377-381.

Sharma, J.R., R.B. Gupta, R.D. Panwar and R.A. Kaushik. 2003. Growth and flowering of Gladiolus as affected by nitrogen and phosphorus levels. J. Ornam. Horticul. New Ser., 6: 76-77.

Sidhu, G.S. and J.S. Arora. 1989. Response of gladiolus varieties to nitrogen application. Indian J. Hort., 46: 250-254.

Thalooth, A.T., M.M. Tawfic and H.M. Mohamed. 2006. Comparative study on the effect of foliar application of $Z$ inc, potassium and magnesium on growth, yield, and some chemical constituents of mungbean plants grown under water stress conditions. World J. Agric. Sci., 2: 3746.

Verma,S.K. and M.Verma.2007.A textbook of plant physiology, biochemistry and biotechnology. S. Chand \& Company Ltd., New Delhi, pp. 110112.

Wilfret, G.J. 1980. Gladiolus: Introduction to floriculture. Academic Press, Inc., New York, pp. 165-181. https://doi.org/10.1016/B978-012-437650-2.50011-1

Younis, A., M. Ahmad and A. Riaz. 2006. Effect of different potting media on growth and flowering of dahlia coccinia cv. 'Mignon'. Acta Hort., 804: 191-196.

Zorb C., M. Senbayram and E. Peiter. 2014. Potassium in agriculture - Status and perspectives. J. Plant Physiol., 171: 656-669.

Zubair, M. 2011. Effect of potassium fertility levels on gladiolus yield quality of cut flowers and corm production. Egyptian Acad. J. Biol. Sci., 2: 17-27. https://doi.org/10.21608/ eajbsh.2011.17008

Zubair, M., G. Ayub, F.K. Wazir, M. Khan and Z. Mahmood. 2006. Effect of potassium on prefowering growth of gladiolus cultivars. J. Agric. Biol. Sci., 1: 36-46. 